\title{
Dopaminergic and Glutamatergic Signaling Crosstalk in Huntington's Disease Neurodegeneration: The Role of p25/ Cyclin-Dependent Kinase 5
}

\author{
Paola Paoletti, ${ }^{1,2}$ Ingrid Vila, ${ }^{1,2}$ Maria Rifé, ${ }^{1,2}$ José Miguel Lizcano, ${ }^{3}$ Jordi Alberch, ${ }^{1,2}$ and Silvia Ginés ${ }^{1,2}$ \\ ${ }^{1}$ Departament de Biologia Cellular, Immunologia i Neurociències, Facultat de Medicina, Institut d'Investigacions Biomèdiques August Pi i Sunyer and \\ ${ }^{2}$ Centro de Investigación Biomédica en Red sobre Enfermedades Neurodegenerativas, Universitat de Barcelona, E-08036 Barcelona, Spain, and ${ }^{3}$ Institut de \\ Neurociències i Departament de Bioquímica i Biologia Molecular, Universitat Autònoma de Barcelona, E-08193 Barcelona, Spain
}

\begin{abstract}
Altered glutamatergic and dopaminergic signaling has been proposed as contributing to the specific striatal cell death observed in Huntington's disease (HD). However, the precise mechanisms by which mutant huntingtin sensitize striatal cells to dopamine and glutamate inputs remain unclear. Here, we demonstrate in knock-in HD striatal cells that mutant huntingtin enhances dopaminemediated striatal cell death via dopamine $\mathrm{D}_{1}$ receptors. Moreover, we show that NMDA receptors specifically potentiate the vulnerability of mutant huntingtin striatal cells to dopamine toxicity as pretreatment with NMDA increased $\mathrm{D}_{1} \mathrm{R}$-induced cell death in mutant but not wild-type cells. As potential underlying mechanism of increased striatal vulnerability, we identified aberrant cyclin-dependent kinase 5 (Cdk5) activation. We demonstrate that enhanced Cdk5 phosphorylation and increased calpain-mediated conversion of the Cdk5 activator p35 into p25 may account for the deregulation of Cdk5 associated to dopamine and glutamate receptor activation in knock-in HD striatal cells. Moreover, supporting a detrimental role of $\mathrm{Cdk} 5$ in striatal cell death, neuronal loss can be widely prevented by roscovitine, a potent Cdk5 inhibitor. Significantly, reduced Cdk5 expression together with enhanced Cdk5 phosphorylation and p 25 accumulation also occurs in the striatum of mutant $H d h^{Q 111}$ mice and HD human brain suggesting the relevance of deregulated Cdk5 pathway in HD pathology. These findings provide new insights into the molecular mechanisms underlying the selective vulnerability of striatal cells in $\mathrm{HD}$ and identify p25/Cdk5 as an important mediator of dopamine and glutamate neurotoxicity associated to HD.
\end{abstract}

Key words: striatum; neurotoxicity; huntingtin; dopamine $\mathrm{D}_{1}$ receptors; glutamate; $\mathrm{p} 25$

\section{Introduction}

Huntington's disease (HD) is a progressive neurological disorder characterized by chorea, cognitive decline, and psychiatric disturbances (MacDonald et al., 2003; Pérez-Navarro et al., 2006). Dysfunction and death of striatal medium-spiny neurons is the major feature of neuropathological changes in HD (Martin and Gusella, 1986; de la Monte et al., 1988). Although it is not known why spiny neurons are preferentially targeted for degeneration, there is evidence to support the idea that mutant huntingtin toxicity may involve excitotoxicity caused by aberrant NMDA receptor activation (Pérez-Navarro et al., 2006; Fan and Raymond, 2007). In addition to glutamatergic afferents, the striatum also receives the densest dopaminergic innervation in the brain from the ventral midbrain neurons. Despite the high concentration of

\section{Received July 10, 2008; accepted Aug. 18, 2008.}

This work was supported by grants from Ministerio de Educación y Ciencia, Centro de Investigaciones Biomédicas en Red sobre Enfermedades Neurodegenerativas, Fundació La Marató de TV3, and HighQ Foundation. P.P. and M.R. are fellows of the HighQ Foundation. We thank Dr. M. Macdonald for the knock-in striatal cell lines and knock-in HD mice and Dr. P Davis for tau antibodies. We are very grateful to Cristina Herranz, Ana Lopez, and M. Teresa Muñoz for technical assistance. We thank Banc de Teixits Neurològics (University of Barcelona, Barcelona, Spain) for human tissue samples. We thank C. A. Saura and members of our laboratory for helpful discussion.

Correspondence should be addressed to Silvia Ginés, Universitat de Barcelona, Casanova 143, E-08036 Barcelona, Spain. E-mail: silviagines@ub.edu.

D0I:10.1523/JNEUROSCI.3237-08.2008

Copyright $\odot 2008$ Society for Neuroscience $\quad$ 0270-6474/08/2810090-12\$15.00/0 dopamine (DA) in the striatum, a number of studies have revealed a potential toxic role of DA in the nervous system (Jakel and Maragos, 2000). Thus, exposure of primary striatal neurons to DA causes significant neurotoxicity with increased free radical production and accelerated neuronal death (Wersinger et al., 2004). Moreover, there is increasing evidence that the dopaminergic system may contribute to HD neuropathology. Data from striatal primary neurons that express exon-1 mutant huntingtin indicates that DA exacerbates mutant huntingtin toxicity via reactive oxygen species production and $\mathrm{D}_{2}$ receptor activation (Charvin et al., 2005; Benchoua et al., 2008). Furthermore, in double mutant mice expressing endogenous levels of exon-1 mutant huntingtin and knock-out for the dopamine transporter, DA accelerates protein aggregation and motor dysfunction (Cyr et al., 2006). These data suggest that disturbed DA and NMDA signaling may participate in the enhanced sensitivity of striatal neurons to huntingtin toxicity. In this line, Tang et al. (2007) have reported that dopamine potentiates glutamate-induced apoptosis in cultured striatal neurons from YAC128 HD mice via activation of $\mathrm{D}_{1}$ receptors. However, little is known about the molecular mechanisms that underlie the increased vulnerability of mutant huntingtin striatal cells to dopamine and glutamate inputs.

Cyclin-dependent kinase $5(\mathrm{Cdk} 5)$ is a serine/threonine ki- 
nase whose activity is primarily restricted to the nervous system where its main activator p35 is expressed. Although Cdk5 is essential for brain development, many neurodegenerative diseases involve sustained activation of Cdk5 in neurons (Cruz and Tsai, 2004; Dhariwala and Rajadhyaksha, 2008). Several studies indicate that Cdk 5 becomes a cell death inductor when it binds to p25, the calpain-mediated cleaved product of p35 (Lee et al., 2000). Thus, accumulation of p 25 has been observed in neurons treated with glutamate or oxidative stress as well as in animal models of several neurodegenerative diseases (Cruz and Tsai, 2004; Dhariwala and Rajadhyaksha, 2008). Notably, treatment with 3-nitropropionic, the systemic administration of which produces selective striatal degeneration with symptoms resembling those of HD (Beal et al., 1993), induces striatal but not cortical Cdk5 activation (Crespo-Biel et al., 2007; Akashiba et al., 2008). More recently, it has been postulated for $\mathrm{Cdk} 5$ a role in dopaminergic neurodegeneration. Thus, 1-methyl-4-phenyl-1,2,3,6tetrahydropyridine (MPTP)-induced dopaminergic cell loss involves enhanced Cdk5 activity and increased conversion of $\mathrm{p} 35$ to the pathogenic p25 form (Smith et al., 2003, 2006).

The above observations prompted us to explore the involvement of aberrant glutamatergic and dopaminergic signaling in striatal neurodegeneration in HD to determine whether Cdk5 might account for this neurotoxic effect. Our data suggest that mutant huntingtin alters NMDAR and $D_{1} R$ signaling via Cdk5 to increase the vulnerability of striatal cells to neurotoxicity.

\section{Materials and Methods}

Reagents and antibodies. NMDA, $( \pm)$-SKF-38393 hydrochloride, $( \pm)$ Quinpirole dihydrochloride, $\mathrm{R}(+)-\mathrm{SCH}-23390$ hydrochloride, (-)-MK801 hydrogen maleate, EGTA, roscovitine, and SP600125 were obtained from Sigma-Aldrich. Hoechst 33258 pentahydrate was from Invitrogen. Anti-p35 (C-19), anti-phospho-Cdk5 (Tyr ${ }^{15}$ ), and anti-Cdk5 (J-3) antibodies were purchased from Santa Cruz Biotechnology. Anti-phosphostress-activated protein kinase (SAPK)/c-Jun N-terminal protein kinase (JNK) $\left(\mathrm{Thr}^{183} / \mathrm{Tyr}^{185}\right.$ ) and anti-SAPK/JNK were from Cell Signaling Technologies. Paired helical filament (PHF)-1 and TG5 anti-tau antibodies were a generous gift from Peter Davis (Albert Einstein College of Medicine, Bronx, NY). Anti-green fluorescent protein (GFP) was obtained from Clontech. Anti- $\alpha$-spectrin was purchased from Millipore. Anti- $\alpha$-tubulin was from Sigma-Aldrich.

Cell cultures. Conditionally immortalized wild-type $\mathrm{STHdh}^{\mathrm{Q} 7}$ and mutant STHdh ${ }^{\text {Q111 }}$ striatal neuronal progenitor cell lines expressing endogenous levels of normal and mutant huntingtin with 7 and 111 glutamines, respectively, have been described previously (Trettel et al., 2000). Striatal cells were grown at $33^{\circ} \mathrm{C}$ in DMEM (Sigma-Aldrich), supplemented with $10 \%$ fetal bovine serum (FBS), 1\% streptomycinpenicillin, $2 \mathrm{~mm}$ L-glutamine, $1 \mathrm{~mm}$ sodium pyruvate, and $400 \mu \mathrm{g} / \mathrm{ml}$ G418 (Geneticin; Invitrogen).

Genetic Huntington's disease mouse model and postmortem brain tissues. $H d h^{Q 111}$ knock-in mice expressing mutant huntingtin with 111 glutamine residues have been described previously (Wheeler et al., 1999). Animals were deeply anesthetized with $\mathrm{CO}_{2}$ and decapitated. Striatum was dissected from 9-month-old homozygous mutant $H d h^{\mathrm{Q} 111 / \mathrm{Q} 111}$ and wild-type $H d h^{Q 7 / Q 7}$ littermate offspring, obtained from the mating of male and female $H d h^{\mathrm{Q} 111 / \mathrm{Q} 7}$ heterozygotes. The animals were housed under a $12 \mathrm{~h}$ light/dark cycle with food and water ad libitum. All procedures were performed in accordance with the National Institutes of Health and were approved by the local animal care committee of the Universitat de Barcelona (99/01) and the Generalitat de Catalunya (00/1094).

Samples of the caudate and putamen nucleus from three patients with $\mathrm{HD}$ (with death at end-stage disease at 71,68 , and 65 years, postmortem intervals of $4-15 \mathrm{~h}$ ) and three control cases $(42,77$, and 74 years, postmortem intervals of $4-23 \mathrm{~h}$ ) were supplied by the Banc de Teixits Neurològics (Servei Científico-Tècnic, Universitat de Barcelona, Barcelona,
Spain). All of the ethical guidelines contained within the latest Declaration of Helsinki were taken into consideration, and informed consent was obtained from all subjects under study.

Drug treatments of striatal cell lines. To induce NMDA excitotoxicity, wild-type STHdh ${ }^{\mathrm{Q7}}$ and mutant knock-in STHdh ${ }^{\mathrm{Q} 111}$ striatal cells were exposed to 500 or $50 \mu \mathrm{M}$ NMDA in Locke's solution (154 mM NaCl, 5.6 mм KCl, $2.3 \mathrm{~mm} \mathrm{CaCl}_{2}, 3.6 \mathrm{~mm} \mathrm{NaHCO}_{3}, 5 \mathrm{~mm}$ HEPES, $5.6 \mathrm{~mm}$ glucose, and $10 \mu \mathrm{m}$ glycine) for $30 \mathrm{~min}$. After treatment, the medium was replaced by fresh DMEM medium with $2.5 \%$ FBS.

To assess the effect of dopamine receptor activation, wild-type STH$\mathrm{dh}^{\mathrm{Q} 7}$ and mutant STHdh ${ }^{\mathrm{Q} 111}$ striatal cells were treated for $24 \mathrm{~h}$ in DMEM medium (2.5\% FBS) with different concentrations of the $\mathrm{D}_{1}$ receptor agonist SKF38393 $(30,60,80$, or $100 \mu \mathrm{M})$ or the $\mathrm{D}_{2}$ receptor agonist quinpirole $(30,60$, or $150 \mu \mathrm{M})$.

In some experiments, cultures were treated with the $\mathrm{D}_{1}$ receptor antagonist (SCH-23390, $10 \mu \mathrm{M}$ ), the JNK inhibitor (SP600125, $10 \mu \mathrm{M}$ ), or the Cdk5 inhibitor (roscovitine, $20 \mu \mathrm{M}$ ) $1 \mathrm{~h}$ before NMDA or SKF38393 treatments.

To study Cdk5 and p35/p25 protein levels, wild-type STHdhQ7 and mutant knock-in STHdhQ111 striatal cells were first placed in DMEM serum-free medium for $3 \mathrm{~h}$. For the NMDA treatment, cells were exposed to $500 \mu \mathrm{M}$ NMDA in Locke's solution for $30 \mathrm{~min}$. After treatment, the medium was replaced by fresh DMEM serum-free medium, and total cell extracts were obtained at different time periods (5, 15, 30, and $60 \mathrm{~min}$ ). For the SKF38393 treatment, cells were exposed to Locke's solution for $30 \mathrm{~min}$ before the addition of SKF38393 $(100 \mu \mathrm{M})$ in fresh DMEM serum-free medium. Total extracts were obtained at different time periods $(5,15,30$, and $60 \mathrm{~min})$ after SKF38393 treatment. Finally, to assess the combined treatment, cells were pre-exposed to $500 \mu \mathrm{M}$ NMDA in Locke's solution for $30 \mathrm{~min}$. After treatment, the medium was replaced by fresh DMEM serum-free medium containing $100 \mu \mathrm{M}$ SKF38393 and total cell extracts were obtained at different time periods $(5,15,30$, and 60 min) after SKF38393 treatment.

To test the role of calcium influx in the p35/p25 protein levels, mutant STHdhQ111 striatal cells were first placed in DMEM serum-free medium for $3 \mathrm{~h}$ and then exposed to $25 \mu \mathrm{M}$ MK-801 or $400 \mu \mathrm{M}$ EGTA in DMEM serum-free medium for $6 \mathrm{~h}$. Total cell extracts were obtained after treatment.

Cell survival. Cell survival was assessed by nuclear DNA staining with Hoechst 33258. Cells were washed twice with PBS, fixed with $4 \%$ paraformaldehyde in PBS for 10 min, washed twice in PBS, and stained with Hoechst $33258(1 \mu \mathrm{g} / \mathrm{ml})$ for $5 \mathrm{~min}$. Stained cells were then washed twice with PBS and mounted under glass coverslips with Mowiol. Cell survival is represented as the proportion of Hoechst-stained nuclei counted in treated cells compared with the number of control (vehicle-treated) cells $(100 \%)$. Forty fields were counted per condition and experiment, comprising at least 30-40 cells. Data are given as mean \pm SD of values obtained in three independent experiments performed in triplicate.

Cell transfection. For the study of polyQ length-dependent Cdk5 and p-Cdk5 expression, wild-type $\mathrm{STHdh}{ }^{\mathrm{Q} 7}$ striatal cells were transfected using Lipofectamine 2000 as described by the manufacturer (Invitrogen). Wild-type STHdh ${ }^{\mathrm{Q} 7}$ at $50 \%$ confluence were transfected with three different constructs containing the mutant exon 1 of the huntingtin gene with different CAG/CAA repeats and with enhanced GFP: 23, Q23htt; 72, Q72htt and 103, Q103htt (Kazantsev et al., 1999) (generously provided by Dr. George M. Lawless, Cure HD Initiative, Reagent Resource Bank of the Hereditary Disease Foundation, New York, NY). The protein extracts were prepared $24 \mathrm{~h}$ after transfection.

Western blot analysis. Total cellular extracts were collected in lysis buffer containing $50 \mathrm{~mm}$ Tris base, $\mathrm{pH}$ 7.4, $150 \mathrm{~mm} \mathrm{NaCl}, 2$ mм EDTA, $0.1 \mathrm{~mm}$ phenylmethylsulphonyl fluoride, $1 \% \mathrm{NP}-40$, and supplemented with $1 \mathrm{~mm}$ sodium orthovanadate and protease inhibitor mixture (Sigma-Aldrich). Samples were centrifuged at $10,000 \times g$ for $10 \mathrm{~min}$ and the protein contents determined by (detergent-compatible) protein assay (Bio-Rad). Protein extracts $(20-40 \mu \mathrm{g})$ were mixed with $5 \times$ SDS sample buffer, boiled for $5 \mathrm{~min}$, resolved by $8-10 \%$ SDS-PAGE, and transferred to nitrocellulose membranes (Whatman Schleicher and Schuell). Blots were blocked in 10\% nonfat powdered milk in TBS-T (50 mm Tris- $\mathrm{HCl}, 150 \mathrm{~mm} \mathrm{NaCl}, \mathrm{pH}$ 7.4, 0.05\% Tween 20) for $30 \mathrm{~min}$ at 
room temperature. The membranes were then incubated overnight at $4^{\circ} \mathrm{C}$ with primary antibodies [phospho-JNK $\left(\mathrm{Thr}^{183} / \mathrm{Tyr}^{185}\right)(1: 1000)$, total JNK (1:1000), p35 (1:1000), phospho-Cdk5 $\left(\mathrm{Tyr}^{15}\right)$ (1:5000), total Cdk5 (1:1000), GFP (1:500), $\alpha$-spectrin (1:1000), TauG5 (1:500), PHF-1 (1:500), or $\alpha$-tubulin $(1: 50,000)]$. The membranes were then rinsed three times with Tris-buffered saline-Tween 20 (TBS-T) and incubated with horseradish peroxidase-conjugated secondary antibody for $1 \mathrm{~h}$ at room temperature. After washing for $30 \mathrm{~min}$ with TBS-T, the membranes were developed using the enhanced chemiluminescence substrate kit (Santa Cruz Biotechnology). The Gel-Pro densitometry program (Gel-Pro Analyzer for Windows, version 4.0.00.001) was used to quantify the different immunoreactive bands relative to the intensity of the $\alpha$-tubulin band in the same membranes. We ensured signals were within a linear range of detection for the ECL reagent on Hyperfilm ECL (GE Healthcare) by probing increasing amounts of lysate with the relevant antibody. Data are expressed as the mean \pm SD of band density obtained in three independent experiments.

Cdk5 kinase activity. Cdk5 was immunoprecipitated with $1 \mu \mathrm{g}$ of antiCdk5 agarose conjugated antibody (C-8; Santa Cruz Biotechnology) from $500 \mu \mathrm{g}$ of total cell lysates obtained from wild-type STHdh ${ }^{\mathrm{Q7}}$ and mutant STHdh ${ }^{\mathrm{Q} 111}$ striatal cells treated with $100 \mu \mathrm{M}$ SKF38393 alone or pre-exposed (30 min) to NMDA before SKF38393 treatment. The immunoprecipitates were washed three times with lysis buffer and twice with kinase buffer ( $50 \mathrm{~mm}$ Tris, $\mathrm{pH} 7.5,0.1 \% \beta$-mercaptoethanol, $0.1 \mathrm{~mm}$ EGTA, 0.1 mM EDTA). The standard assay contained the following (50 $\mu \mathrm{l}$ total volume): washed agarose immunoprecipitate, $50 \mathrm{~mm}$ Trs- $\mathrm{HCl}, \mathrm{pH}$ 7.5, $0.1 \mathrm{~mm}$ EGTA, $0.1 \% \beta$-mercaptoethanol, $10 \mathrm{~mm}$ magnesium acetate, $0.1 \mathrm{~mm}\left[\gamma^{-}{ }^{32} \mathrm{P}\right]$-ATP $(5 \mu \mathrm{Ci})$, and $200 \mu \mathrm{M}$ of substrate (peptide histone 1 ; Jena Bioscience). The assays were performed for $60 \mathrm{~min}$ at $30^{\circ} \mathrm{C}$, and the assay tubes were agitated continuously to keep the immunoprecipitate in suspension. Incorporation of $\left[\gamma_{-}{ }^{32} \mathrm{P}\right]$-phosphate into peptide substrate was determined using $\mathrm{p} 81$ phosphocellulose paper. Papers were washed in $0.5 \%$ ortophosphoric acid, dried, and Cherenkov radiation was counted. Control experiments were performed in parallel without the peptide substrate.

Statistical analysis. All of the data were analyzed with the program Graph Pad Prism version 4.0 (GraphPad Software). Results are expressed as mean $\pm \mathrm{SD}$. Experimental data were analyzed either by a one- or two-way ANOVA followed by the post hoc Bonferroni's multiple comparison test or by Student's $t$ test. A value of $p<0.05$ was accepted as denoting statistical significance.

\section{Results \\ $D_{1}$ receptor activation increases neuronal death in STHdh ${ }^{\text {Q111 }}$ striatal cells}

To determine whether mutant huntingtin enhances the vulnerability of striatal cells to dopamine, immortalized striatal cells expressing endogenous levels of full-length wild-type STHdh ${ }^{\mathrm{Q7}}$ or mutant STHdh ${ }^{\text {Q111 }}$ huntingtin were treated with increasing concentrations of the $D_{1}$ receptor agonist SKF38393 $(0-100 \mu \mathrm{M})$ or the $\mathrm{D}_{2}$ receptor agonist quinpirole $(0-150 \mu \mathrm{M})$ followed by the determination of cell survival. SKF38393 treatment caused a dose-dependent increase in neuronal cell death in both wild-type and mutant striatal cells (Fig. 1A). Two-way ANOVA analysis for drug treatment and genotype showed that the effect was statistically significant $\left(F_{(4,15)}=444.30, p<0.001 ; F_{(1,15)}=192.04, p \leq\right.$ 0.001 , respectively). Importantly, the interaction between genotype and treatment was also statistically significant $\left(F_{(4,15)}=\right.$ 31.69; $p<0.001)$, indicating that the two cell genotypes responded differently to the SKF38393 treatment. Thus, at all SKF38393 concentrations tested, the reduction in cell survival was significantly higher in mutant STHdh ${ }^{\mathrm{Q} 111}$ than it was in wild-type STHdh ${ }^{\mathrm{Q7}}$ cells, with a maximal difference detected at $100 \mu \mathrm{M}$ SKF38393 (wild type, $64 \pm 11 \%$ vs mutant, $39 \pm 6 \%$; $p \leq$ $0.001)$. It should be noted that (1) at the lower tested concentration (SKF38393 $30 \mu \mathrm{M}$ ) only mutant huntingtin STHdh ${ }^{\text {Q111 }}$ cells exhibited a reduction in cell survival $(\sim 20 \%$; $p \leq 0.001)$, and (2)
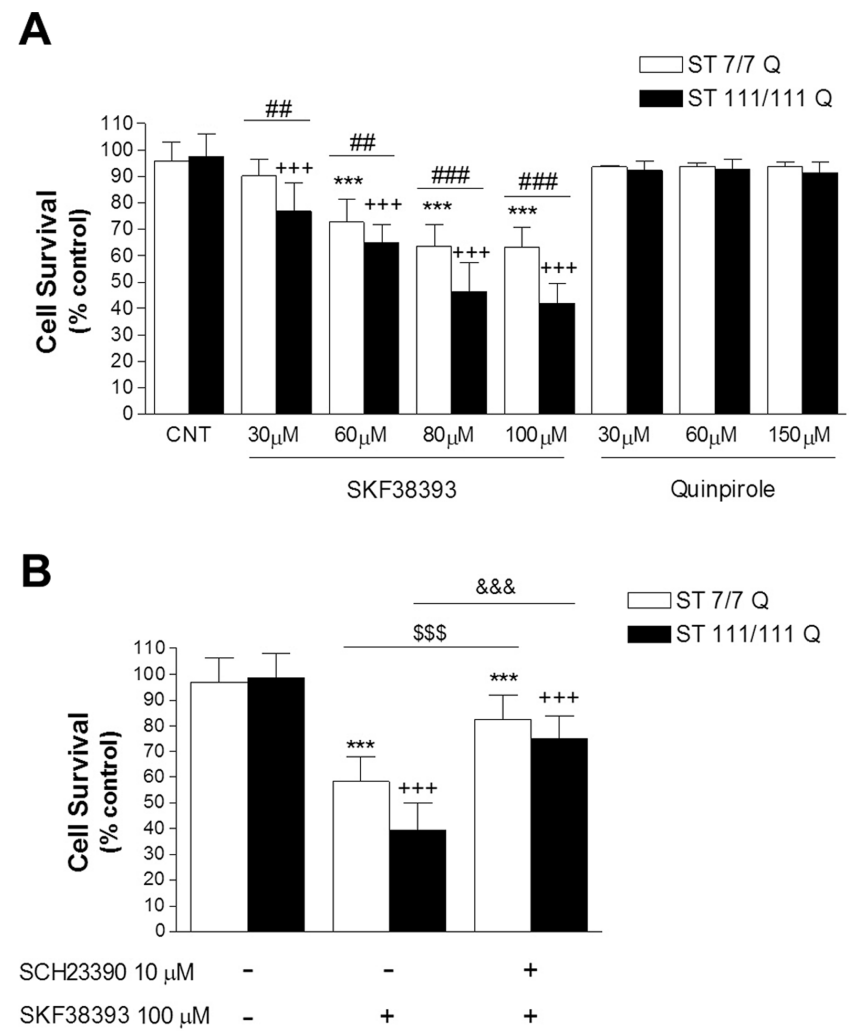

Figure 1. Increased dopamine $D_{1}$-receptor-mediated cell death in STHdh ${ }^{0111}$ striatal cells. A, Wild-type (ST7/7Q) and mutant (ST1111/111Q) striatal cells were treated with different concentrations of the $D_{1}$ receptor agonist SKF38393 $(30,60,80$, or $100 \mu \mathrm{m})$ or the $D_{2}$ receptor agonist quinpirole $(30,60$, or $150 \mu \mathrm{m})$ during $24 \mathrm{~h}$. After treatment, cell survival was measured by scoring the percentage of Hoechst-stained nuclei. Forty fields were counted per condition per experiment, comprising at least 30-40 cells. Results are expressed as percentage of control (vehicle-treated) cells, and data are the mean \pm SD of three independent experiments performed in triplicate. A full statistical analysis by the two-way ANOVA is described in the text. ${ }^{* * *} p<0.001$ treated versus vehicle-treated wild-type cells; ${ }^{++}{ }^{++} p<0.001$ treated versus vehicle-treated mutant cells; ${ }^{\# \#} p<0.01,{ }^{\# \# \#} p<0.001$ treated mutant cells versus treated wild-type cells (Bonferroni's multiple comparison test). CNT, Control. B, Wild-type and mutant striatal cells were treated $(1 \mathrm{~h})$ with the $\mathrm{D}_{1}$ receptor antagonist $\mathrm{SCH} 23390(10 \mu \mathrm{m})$ before SKF38393 treatment $(100 \mu \mathrm{m})$. Cell survival was assessed $24 \mathrm{~h}$ later by scoring the percentage of Hoechst-stained nuclei. Forty fields were counted per condition per experiment, comprising at least 30-40 cells. Results are expressed as percentage of control (vehicle-treated) cells, and data are the mean $\pm S D$ of three independent experiments performed in triplicate. ${ }^{* * *} p<$ 0.001 treated versus vehicle-treated wild-type cells; ${ }^{++}{ }^{+} p<0.001$ treated versus vehicletreated mutant cells; ${ }^{\$ \$ \$} p<0.001$ SCH23390 plus SKF38393-treated wild-type cells versus SKF38393-treated wild-type cells; ${ }^{\& \& \&} p<0.001$ SCH23390 plus SKF38393-treated mutant cells versus SKF38393-treated mutant cells as determined by one-way ANOVA followed by Bonferroni's multiple comparison test.

the decrease in cell survival in STHdh ${ }^{\mathrm{Q7}}$ wild-type cells reached a maximum at $80 \mu \mathrm{M}$ SKF38393 (64 $\pm 11 \%$; $p \leq 0.001)$, whereas STHdh ${ }^{\text {Q111 }}$ mutant cells still exhibited higher cell death at 100 $\mu \mathrm{M}$ SKF38393 ( 8\% more compared with $80 \mu \mathrm{M}$ SKF38393; $p \leq$ $0.05)$. Importantly, coincubation with the $\mathrm{D}_{1}$-selective antagonist SCH23390 significantly reduced SKF38393-induced cell death near to that of control levels in both wild-type and mutant huntingtin cells $(\sim 85 \pm 10 \%$ and $79 \pm 11 \%$; $p \leq 0.001$, respectively) (Fig. $1 B$ ). No effect on neuronal survival was observed after stimulation of $\mathrm{D}_{2}$ receptors with quinpirole (Fig. $1 A$ ). Thus, our results imply that $D_{1}$ receptor activation mediates the dopaminergic toxic effect observed in wild-type and mutant knock-in striatal cells and that full-length mutant huntingtin expression potentiates dopamine-cell death through $D_{1}$ but not $D_{2}$ receptors. 
A

ST $7 / 7 Q$

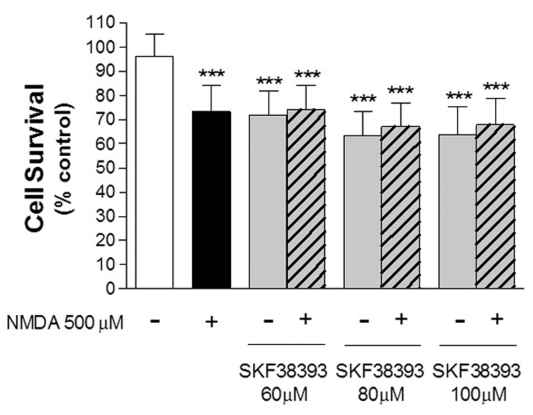

B

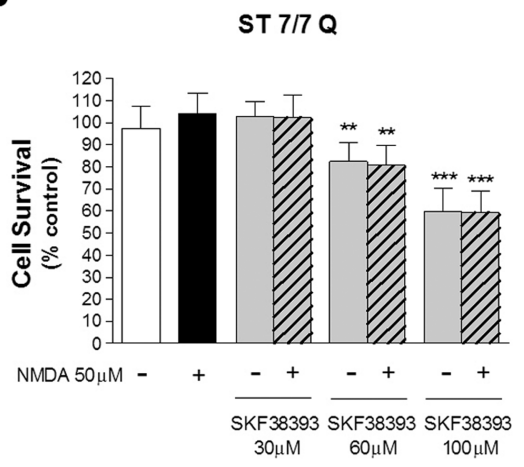

ST $111 / 111 Q$
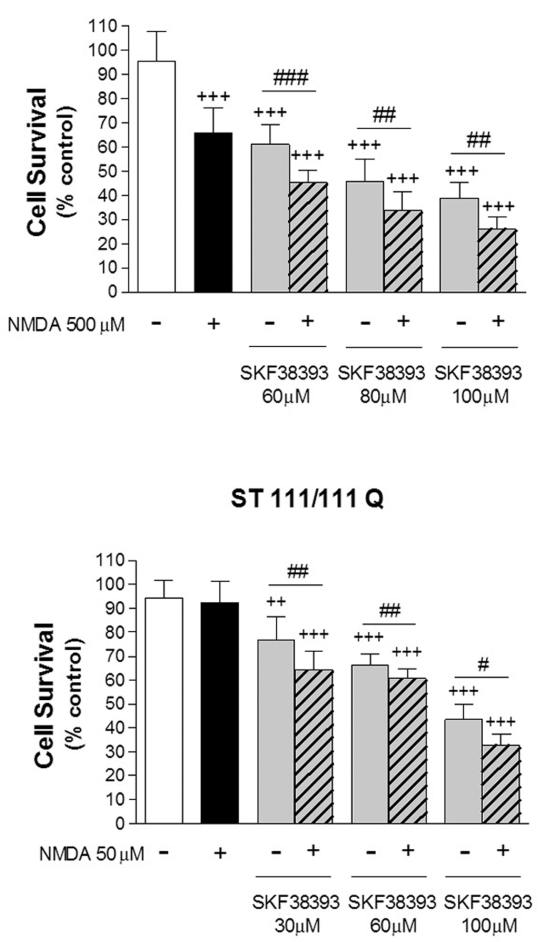

Figure 2. NMDA potentiates the toxic effect of $\mathrm{D}_{1}$-receptor activation in STHdh ${ }^{0111}$ striatal cells. $\boldsymbol{A}$, Wild-type (ST7/70) and mutant (ST111/1110) striatal cells were treated with a toxic concentration of NMDA $(500 \mu \mathrm{M})$ for $30 \mathrm{~min}$ before treatment with different concentrations of SKF38393 $(60,80$, or $100 \mu \mathrm{M})$. Cell survival was assessed $24 \mathrm{~h}$ later by scoring the percentage of Hoechst-stained nuclei. $\boldsymbol{B}$, Wild-type and mutant striatal cells were exposed to a subtoxic concentration of NMDA $(50 \mu \mathrm{m})$ for 30 min before treatment with different concentrations of SKF38393 (30, 60, or $100 \mu \mathrm{M})$. Cell survival was measured $24 \mathrm{~h}$ later by scoring the percentage of Hoechst-stained nuclei. Forty fields were counted per condition per experiment, comprising at least $30-40$ cells. Results are expressed as percentage of control (vehicle-treated) cells, and data are the mean \pm SD of three independent experiments performed in triplicate. A full statistical analysis by the two-way ANOVA is described in the text. ${ }^{* *} p<$ $0.01,{ }^{* * *} p<0.001$ treated versus vehicle-treated wild-type cells; ${ }^{++} p<0.01,{ }^{++} p<0.001$ treated versus vehicle-treated mutant cells; ${ }^{\#} p<0.05,{ }^{\# \#} p<0.01$, \#\#\# $p<0.001$ NMDA plus SKF38393-treated mutant cells versus SKF38393-treated mutant cells (Bonferroni's multiple comparison test).

\section{NMDA enhances dopamine $D_{1}$ receptor-mediated cell death selectively in STHdh ${ }^{\mathrm{Q} 111}$ cells}

Previous results from our laboratory have demonstrated that mutant STHdh ${ }^{\text {Q111 }}$ striatal cells display enhanced sensitivity to NMDA receptor activation (Xifró et al., 2008). Therefore, we next analyzed whether NMDA treatment potentiates the neurotoxic effect of dopamine. We first analyzed the role of a toxic concentration of NMDA $(500 \mu \mathrm{M})$ on cell death induced by $\mathrm{D}_{1} \mathrm{R}$ activation. Wild-type STHdh ${ }^{\mathrm{Q} 7}$ and mutant STHdh ${ }^{\mathrm{Q} 111}$ striatal cells were exposed for $30 \mathrm{~min}$ to NMDA before SKF38393 treatment, and cell survival was analyzed $24 \mathrm{~h}$ later. Pretreatment with NMDA failed to increase SKF38393-induced cell death in wildtype STHdh ${ }^{\text {Q7 }}$ cells (Fig. 2A). Two-way ANOVA for SKF38393 treatment and wild-type group (control and pretreated with NMDA) showed that the effect was statistically significant for drug treatment $\left(F_{(3,12)}=285.6 ; p \leq 0.001\right)$ but not for wild-type group $\left(F_{(1,12)}=0.97 ; p=0.33\right)$. Two-way ANOVA analysis also revealed lack of interaction between factors $\left(F_{(3,12)}=0.38 ; p=\right.$ 0.77). In contrast, mutant STHdh ${ }^{\text {Q111 }}$ striatal cells exhibited a significant decrease in cell survival rates when pre-exposed to NMDA compared with SKF38393 treatment alone (Fig. 2A). Statistical analysis revealed a main effect of NMDA pretreatment in SKF38393-induced cell death in mutant huntingtin striatal cells
$\left[F_{(3,12)}=740.23, p<0.001\right.$ for SKF38393 treatment; $F_{(1,12)}=97.07, p \leq 0.001$ for mutant group (control and pretreated with NMDA) ]. Notably, two-way ANOVA analysis also revealed a statistically significant mutant group $\times$ SKF38393 treatment interaction $\left(F_{(3,12)}=13.4 ; p \leq 0.001\right)$, indicating that mutant huntingtin cells responded differently to SKF38393 treatment when pre-exposed to NMDA toxic concentrations (Fig. 2A). It is important to remark that this effect was observed at concentrations of both SKF38393 and NMDA that induced moderate cell death.

To analyze further the effect of NMDA and SKF38393 on striatal cell death, we next evaluated whether a subtoxic concentration of NMDA $(50 \mu \mathrm{M})$ modulates $\mathrm{D}_{1} \mathrm{R}$-mediated cell death. Consistent with the lack of an additive effect at toxic NMDA concentrations, wild-type STH$\mathrm{dh}^{\mathrm{Q} 7}$ striatal cells pretreated with $50 \mu \mathrm{M}$ NMDA did not show increased cell death to that reported for SKF38393 treatment alone (Fig. 2B). Two-way ANOVA for SKF38393 treatment and wild-type group (control and pretreated with NMDA) showed that the effect was statistically significant for drug treatment $\left(F_{(3,12)}=\right.$ 814.7; $p \leq 0.001)$ but not for wild-type group $\left(F_{(1,12)}=0.92 ; p=0.35\right)$. No interaction between factors was demonstrated by two-way ANOVA analysis $\left(F_{(3,12)}=\right.$ $0.30 ; p=0.82)$. Interestingly, NMDA preexposure was still found to potentiate the cell death induced by SKF38393 treatment in mutant STHdh ${ }^{\text {Q111 }}$ striatal cells $\left[F_{(1,12)}\right.$ $=481.68, p<0.001$ for SKF38393 treatment; $F_{(1,12)}=49.6, p \leq 0.001$ for mutant group (control and pretreated with NMDA)]. Moreover, two-way ANOVA analysis showed that the interaction between factors was statistically significant $\left(F_{(3,12)}=\right.$ 9.07; $p \leq 0.001$ ), which indicates that the curve of dosedependent cell death induced by SKF38393 was different in mutant cells when pre-exposed to subtoxic NMDA concentrations. Together, these data indicate that NMDA enhances the sensibility of mutant but not wild-type striatal cells to $D_{1}$ receptor activation.

JNK activation is not associated with NMDA and SKF38393mediated neurotoxicity in STHdh ${ }^{\mathrm{Q} 111}$ cells

Activation of the JNK may contribute to neuronal cell death after excitotoxicity (Brecht et al., 2005; Centeno et al., 2007). To investigate the potential role of the JNK pathway in the neurotoxic effect of NMDA and SKF38393, wild-type STHdh ${ }^{\text {Q7 }}$ and mutant STHdh ${ }^{\mathrm{Q} 111}$ striatal cells were treated with $500 \mu \mathrm{M}$ NMDA or 100 $\mu \mathrm{M}$ SKF38393, and the levels of total and phospho-JNK were determined by Western blot analysis. The immunoblot results revealed that neither NMDA nor SKF38393 exposure induced phosphoactivation of JNK (Fig. 3A). Moreover, analysis of wildtype and mutant cells exposed to $500 \mu \mathrm{M}$ NMDA for $30 \mathrm{~min}$ before SKF38393 treatment revealed that a combination of both drugs did not increase JNK phosphorylation either (Fig. $3 A$ ). In 
line with the lack of phospho-JNK activation, pre-exposure of wild-type STHdh ${ }^{\text {Q7 }}$ and mutant STHdh ${ }^{\text {Q111 }}$ huntingtin cells to $10 \mu \mathrm{M}$ SP600125, a JNK inhibitor, did not rescue wild-type or mutant cells from neurotoxic cell death mediated by NMDA or SKF38393 or both (Fig. 3B). These results indicate that JNK does not participate in the observed neurotoxicity induced by NMDA or $\mathrm{D}_{1} \mathrm{R}$ activation in STHdh ${ }^{\mathrm{Q} 7}$ and STHdh ${ }^{\text {Q111 }}$ cells.

\section{NMDA potentiates $D_{1} R$-induced phosphorylation of Cdk5 in mutant STHdh ${ }^{\text {Q111 }}$ cells}

Deregulation of Cdk5 activity has been associated to neuronal cell death in several neurodegenerative disorders (Cruz and Tsai, 2004). To determine whether Cdk5 activation was involved in the increased vulnerability of mutant STHdh ${ }^{\text {Q111 }}$ cells to NMDAR and $D_{1} R$ activation, we first analyzed the levels of total and phosphorylated Cdk5 (Tyr 15) in extracts obtained from wild-type STHdh ${ }^{\mathrm{Q} 7}$ and mutant STHdh ${ }^{\text {Q111 }}$ striatal cells (Fig. $4 A$ ). Immunoblot analysis revealed that total Cdk5 levels were lower in mutant cells than they were in wild-type cells ( $\sim 2$-fold; $p \leq 0.001)$, whereas the levels of $\mathrm{p}$-Tyr ${ }^{15} \mathrm{Cdk} 5$ were slightly increased $(\sim 1.2$-fold; $p \leq 0.05)$. Therefore, a significant $\sim 3$-fold increase in the $\mathrm{p}-\mathrm{Tyr}^{15} \mathrm{Cdk} 5 / \mathrm{Cdk} 5$ ratio $(p \leq 0.001)$ was apparent in mutant cells compared with wild-type cells.

To determine whether deregulation of Cdk5 pathway was dependent on mutant huntingtin expression, wild-type striatal cells were transfected with different constructs encoding for green fluorescent protein-tagged exon-1 mutant huntingtin protein with 23, 72, or 103 CAG repeats (Q23, Q72, and Q103), and total extracts were analyzed by Western blot. The results, shown in Figure $4 B$, revealed an inverse relationship between changes in Cdk5 and the length of the CAG repeat. Thus, reduced Cdk5 expression along with higher $\mathrm{Tyr}^{15}$-Cdk5 phosphorylation was found in wild-type striatal cells transfected with 72 or 103 poly-Q containing exon-1 mutant huntingtin compared with those transfected with the normal poly-Q length (Q23). These data suggest that changes on Cdk5 pathway are directly dependent on mutant huntingtin expression.

We next analyzed whether activation of NMDA and $D_{1}$ receptors was associated with changes in $\mathrm{Cdk} 5$ expression and phosphorylation. Exposure of wild-type STHdh ${ }^{\text {Q7 }}$ and mutant STH$\mathrm{dh}^{\mathrm{Q} 11}$ striatal cells to NMDA resulted in a similar timedependent increase in C $\mathrm{dk} 5$ phosphorylation. Statistical analysis using two-way ANOVA revealed a significant time interval effect $\left(F_{(4,25)}=16.03 ; p<0.001\right)$ without differences between genotypes $\left(F_{(1,25)}=3.57 ; p=0.08\right)$ (Fig. $\left.4 C\right)$. The analysis also demonstrated no interaction between factors $\left(F_{(4,25)}=0.57 ; p=0.7\right)$. Thus, the increase in $\mathrm{Cdk} 5$ phosphorylation was already evident at 5 min, maximal at $15 \mathrm{~min}$, and remained high even $60 \mathrm{~min}$ after treatment. In contrast, in the presence of $100 \mu \mathrm{M}$ SKF38393, the kinetic of Cdk5 phosphorylation differed in mutant STHdh ${ }^{\text {Q111 }}$ and wild-type STHdh ${ }^{\text {Q7 }}$ cells (Fig. 4D). Statistical analysis using two-way ANOVA revealed a significant effect of genotype $\left(F_{(1,25)}=39.36 ; p<0.001\right)$

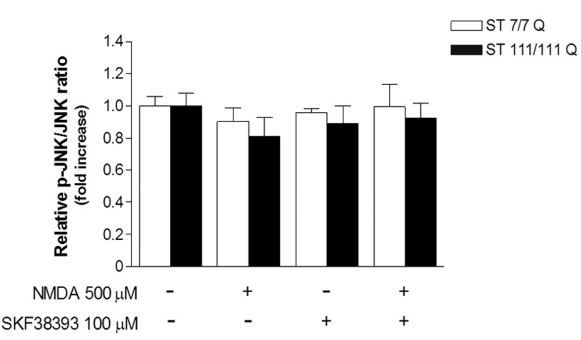

ST $7 / 7 Q$

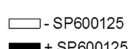

ST $111 / 111 Q$

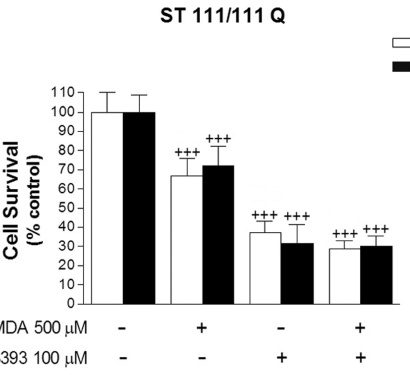

-SP600125

+ SP600125

Figure 3. JNK activation is not associated with NMDA and dopamine-mediated neurotoxicity in wild-type STHdh ${ }^{07}$ and thestern blot showing levels of p-JNK, JNK, and $\alpha$-tubulin as a loading control, fore counted per condition per experiment, comprising at least $30-40$ cells. Results are expressed as percentage of control (vehiclevehicle-treated wild-type cells; ${ }^{++} p<0.001$ treated versus vehicle-treated mutant cells as determined by one-way (t)

and time $\left(F_{(4,25)}=11.85 ; p<0.001\right)$ and a significant genotype $\times$ treatment interaction $\left(F_{(4,25)}=20.16 ; p<0.001\right)$, which demonstrates that the time-dependent phosphorylation of Cdk5 induced by SKF38393 differs between wild-type and mutant huntingtin striatal cells. Thus, wild-type STHdh ${ }^{\text {Q7 }}$ cells and mutant STHdh ${ }^{\text {Q111 }}$ cells showed a significant increase in Cdk5 phosphorylation induced by SKF38393 at 5 min ( $~ 8$-fold; $p \leq 0.001)$. However, at longer periods, no higher increase in $\mathrm{p}-\mathrm{Cdk} 5$ was observed in wild-type

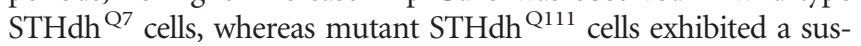
tained increase in $\mathrm{Cdk} 5$ phosphorylation that was maximal at $60 \mathrm{~min}$ after treatment $(\sim 17$-fold; $p \leq 0.001)$ (Fig. $4 D)$. These data suggest a dual role of mutant huntingtin on the Cdk5 pathway by reducing the total expression of Cdk5 and enhancing $\mathrm{D}_{1} \mathrm{R}$-mediated Cdk5 phosphorylation.

Finally, we investigated whether pretreatment with NMDA modified the $\mathrm{D}_{1} \mathrm{R}$-mediated phosphorylation of Cdk5 in wildtype STHdh ${ }^{\text {Q7 }}$ and mutant STHdh ${ }^{\text {Q111 }}$ striatal cells. Exposure of wild-type STHdh ${ }^{\text {Q7 }}$ cells to NMDA before SKF38393 treatment did not change the pattern of Cdk5 phosphorylation compared with SKF38393 alone $\left(F_{(1,25)}=0.89 ; p=0.35\right)$ (Fig. $\left.4 E\right)$. However, mutant STHdh ${ }^{\text {Q111 }}$ cells pre-exposed to NMDA exhibited higher Cdk5 phosphorylation compared with those treated with SKF38393 alone $\left(F_{(1,25)}=147.07 ; p<0.001\right)$ without significant interaction between treatment and time $\left(F_{(4,25)}=2.21 ; p=0.092\right)$. These results demonstrate that in the presence of mutant huntingtin, activation of Cdk 5 by $D_{1} R$ is potentiated by NMDAR activation.

\section{STHdh ${ }^{\text {Q111 }}$ mutant cells exhibited higher p25 levels}

Conversion of p35 into p 25 by $\mathrm{Ca}^{2+}$-dependent calpain activation has been suggested to deregulate Cdk5 activity in several 
A

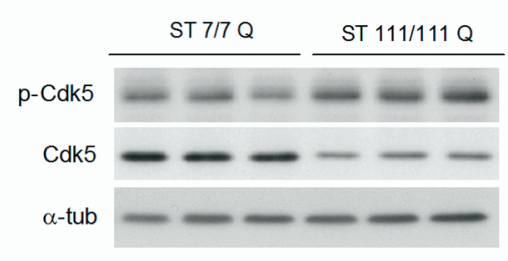

C

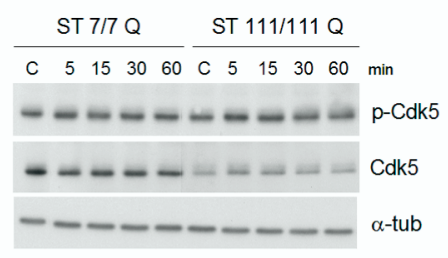

D

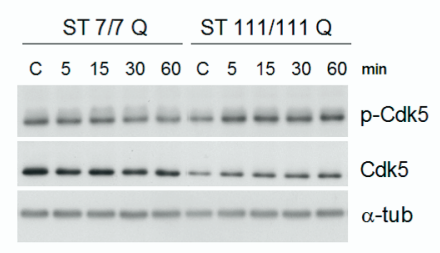

E

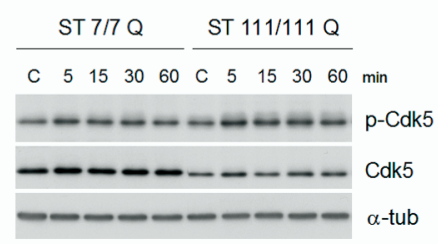

B
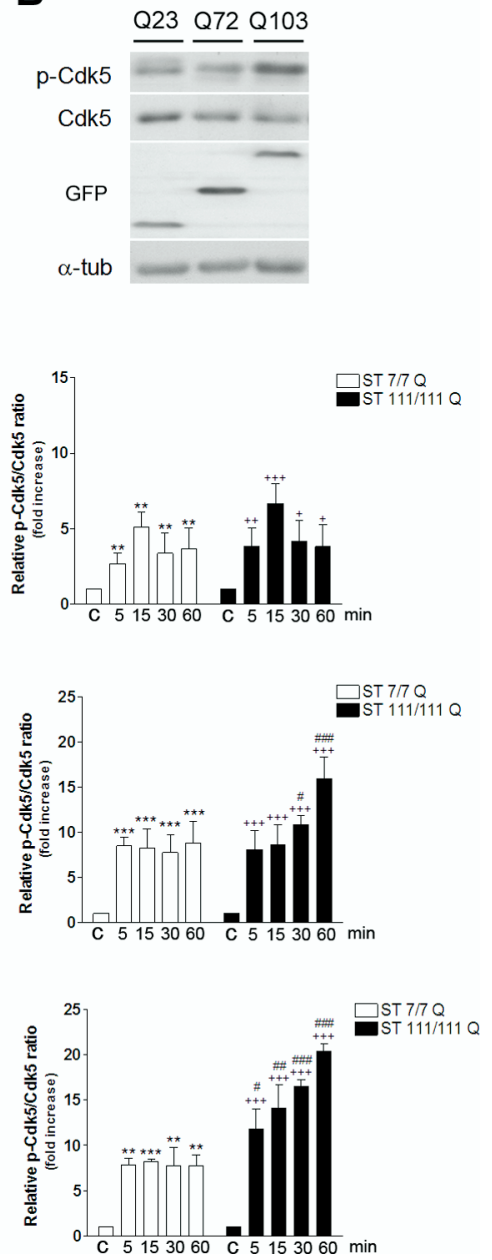

Figure 4. NMDA receptor activation potentiates $D_{1} R$-induced $C d k 5$ phosphorylation in mutant $S T H d h^{0111}$ cells. $A$, Representative Western blot showing levels of $\mathrm{p}$-Cdk5, Cdk5, and $\alpha$-tubulin as a loading control from wild-type (ST7/7Q) and mutant (ST111/111Q) striatal cells. B, Representative Western blot showing levels of $\mathrm{p}$-Cdk5, Cdk5, and GFP and $\alpha$-tubulin as a loading control from wild-type striatal cells transfected with different constructs encoding for enhanced fluorescent protein-tagged exon-1 mutant huntingtin protein with 23 (Q23), 72 (Q72), or 103 (Q103) CAG repeats. C-E, Representative Western blot showing levels of $\mathrm{p}$-Cdk5, Cdk5, and $\alpha$-tubulin as a loading control from wild-type (ST7/7Q) and mutant (ST111/111Q) cell extracts obtained after treatment with NMDA $500 \mu \mathrm{m}$ (C), SKF38393 $100 \mu \mathrm{m}$ (D), or a pretreatment with NMDA before SKF38393 exposure (E). Total cell extracts were obtained at different time periods $(5,15,30$, and $60 \mathrm{~min})$ after treatment. The histograms represent the relative $\mathrm{p}$ - $\mathrm{Cdk5/Cdk5}$ ratio expressed as fold increase versus control (vehicle-treated) cells. Values are given as mean $\pm S D$ of five independent experiments. A full statistical analysis by the two-way ANOVA is described in the text. ${ }^{* *} p<0.01,{ }^{* * *} p<0.001$ treated versus vehicle-treated wild-type cells; ${ }^{+} p<0.05,{ }^{++} p<0.01,{ }^{++} p<0.001$ treated versus vehicle-treated mutant cells; ${ }^{\#} p<0.05,{ }^{\# \#} p<0.01,{ }^{\# \# \#} p<0.001$ treated mutant cells versus treated wild-type cells (Bonferroni's multiple comparison test).

neurodegenerative disorders (Dhariwala and Rajadhyaksha, 2008). Indeed, calpain cleavage turns p 25 into a more stable protein, which results in prolonged Cdk5 activity (Patrick et al., 1999). To examine whether mutant huntingtin altered the levels of p35 or its cleaved product p25, we performed immunoblot analysis using an antibody that recognizes either p35 or p25 forms (Fig. 5A). Our results showed a significant decrease in p35 levels in mutant STHdh ${ }^{\mathrm{Q} 111}$ cells compared with those observed in wild-type STHdh ${ }^{\mathrm{Q} 7}$ cells ( $\sim 2$-fold; $\left.p \leq 0.001\right)$. In contrast, the levels of p25, which were almost undetectable in wild-type STH$\mathrm{dh}^{\mathrm{Q} 7}$ striatal cells, were significantly higher in mutant STH$\mathrm{dh}^{\mathrm{Q} 111}$ cells $(\sim 2.5$-fold; $p \leq 0.001)$. Because $\mathrm{p} 25$ results from calpain activity, using Western blot we next measured the breakdown products of spectrin (SBDP), a well known calpain substrate that yields specific products at $150 / 160 \mathrm{kDa}$ after calpain

cleavage. Consistent with higher p25 accumulation, mutant STHdh ${ }^{\text {Q111 }}$ cells exhibited increased levels of SBDP at 150/160 $\mathrm{kDa}$ compared with wild-type cells $(\sim 2$ fold; $p \leq 0.05$ ) (Fig. 5B). Given that calpain activity is calcium dependent, and because of the fact that mutant STHdh ${ }^{\text {Q111 }}$ cells exhibit at basal levels enhanced NMDAR activation (Gines et al., 2003; Seong et al., 2005), we next evaluated whether p25 accumulation might be a consequence of increased NMDARmediated calcium influx. To test this hypothesis, mutant huntingtin cells were treated with MK-801, a specific NMDAR antagonist that blocks calcium influx associated to NMDAR activation or with the calcium chelator EGTA. Immunoblot analysis revealed that $\mathrm{p} 25$ levels in mutant cells treated with MK-801 or EGTA were lower than those observed in untreated mutant cells $(\sim 1.2$-fold decrease; $p \leq$ 0.01 ), although still significantly higher compared with wild-type cells $(\sim 2.4$ fold increase; $p \leq 0.001$ ) (Fig. $5 C$ ). Importantly, this reduction in p25 levels parallels the increase of p35 levels $(\sim 1.1$ fold increase; $p \leq 0.01$ ) (Fig. $5 C$ ). These data suggest that endogenous activation of NMDAR in mutant striatal cells is not the major contributor to p25 accumulation.

We next evaluated whether either costimulation of NMDAR and $D_{1}$ R or single activation induced higher accumulation of p25. Surprisingly, compared with untreated cells, all treatments failed to increase the accumulation of $\mathrm{p} 25$ any further in both wild-type and mutant striatal cells (Fig. 5D-F). These findings suggest that mutant huntingtin expression is sufficient to induce the conversion of p35 into p25 and support the idea that accumulation of p25 in parallel with higher Cdk5 activity may contribute to the increased vulnerability of mutant STHdh ${ }^{\text {Q111 }}$ striatal cells to NMDA and $D_{1}$ R activation.

\section{Increased Cdk5 activity and tau phosphorylation in STHdh ${ }^{\text {Q111 }}$ mutant cells}

Our previous results have demonstrated higher phosphorylation of Cdk5 induced by $\mathrm{D}_{1} \mathrm{R}$ activation alone or combined by preexposure to NMDA in mutant compared with wild-type striatal cells. To determine whether increased Cdk5 phosphorylation and accumulation of p25 was associated to higher Cdk5 activation, kinase activity was determined in vitro by using Cdk5 immunoprecipitated from untreated or treated (SKF38393 alone or combined with NMDA) wild-type STHdh ${ }^{\text {Q7 }}$ and mutant STHdh ${ }^{\text {Q111 }}$ striatal cells. Our results showed that at basal conditions mutant striatal cells exhibited a significant increase in Cdk5 activity compared with wild-type striatal cells $(\sim 2.5$-fold; $p \leq 0.01)$ (Fig. $6 A$ ). Interestingly, whereas NMDA exposure before SKF38393 treatment did not further increase Cdk5 activity in wild-type striatal 
A

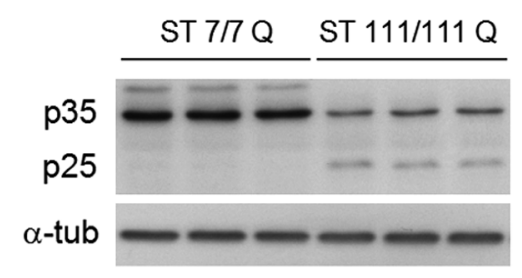

B

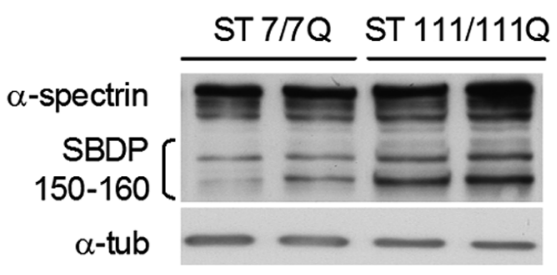

C

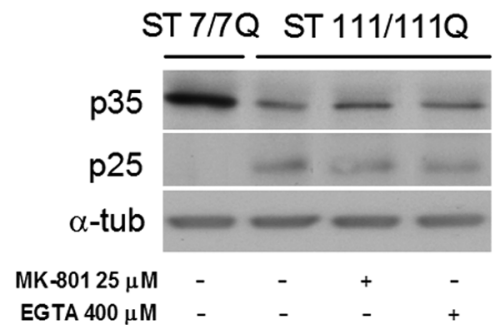

D

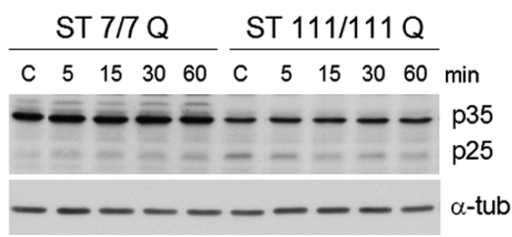

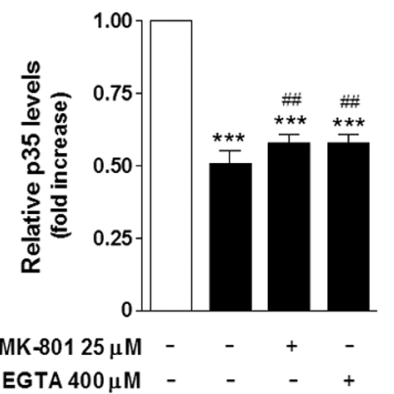

$\mathbf{E}$

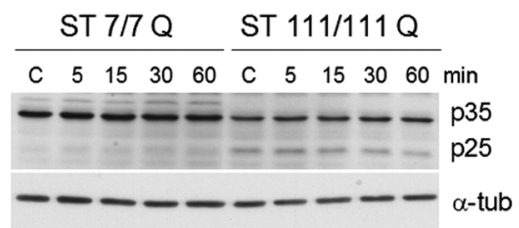

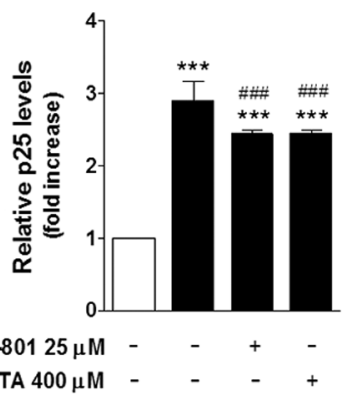

$\mathbf{F}$

Figure 5. Increased p25/p35 levels in mutant STHdh ${ }^{Q 111}$ striatal cells. $A$, Representative Western blot showing levels of p35, p25, and $\alpha$-tubulin as a loading control from wild-type (ST7/70) and mutant (ST111/111Q) striatal cells. B, Representative Western blot showing $\alpha$-spectrin and SDBP (150-160 kDa) and $\alpha$-tubulin as a loading control from wild-type (ST7/70) and mutant (ST111/111Q) striatal cells. C, Representative Western blot showing levels of p35, p25, and $\alpha$-tubulin as a loading control from wild-type and mutant striatal cells treated with MK-801 $25 \mu$ m or EGTA $400 \mu \mathrm{m}$ for $6 \mathrm{~h}$. The histograms represent the relative $\mathrm{p} 35$ and $\mathrm{p} 25$ levels expressed as fold increase versus wild-type cells. Values are given as mean \pm SD of three independent experiments. ${ }^{* * *} p<$ 0.001 mutant cells versus wild-type cells; ${ }^{\# \#} p<0.01,{ }^{\# \# \#} p<0.001$ treated versus vehicle-treated mutant cells as determined by one-way ANOVA followed by Bonferroni's multiple comparison test. $\boldsymbol{D}-\boldsymbol{F}$, Representative Western blot showing p35 and p25 levels and $\alpha$-tubulin as a loading control from wild-type and mutant striatal cells treated with NMDA $500 \mu \mathrm{m}$ alone (D), SKF38393 $100 \mu \mathrm{M}$ alone $(\boldsymbol{E})$, or pretreated with NMDA before SKF38393 exposure $(\boldsymbol{F})$. Total extracts were obtained at different time periods $(5,15,30$, and 60 min) after treatment. $(n=3$ independent experiments).

cells compared with SKF38393 alone $(\sim 1.2$-fold and $\sim 1.3$-fold, respectively; $p=0.53)$, in mutant striatal cells NMDA significantly potentiates $\mathrm{D}_{1} \mathrm{R}$-induced Cdk5 activity $(\sim 1.9$-fold, $p \leq$ 0.001 and $\sim 2.8$-fold, $p \leq 0.001$, respectively) (Fig. $6 A$ ). In support of enhanced Cdk5 activity in mutant striatal cells, Western blot analysis using antibodies specific for phosphorylated tau (PHF-1, Ser ${ }^{396}$ and Ser ${ }^{404}$ ) showed increased tau phosphorylation in basal mutant striatal cells compared with wild-type cells without changes on total tau levels $(\sim 1.5$-fold increase; $p \leq$ 0.05). Consistent with our results on Cdk5 activity, the levels of tau phosphorylation in wild-type cells pretreated with NMDA were similar than those detected in wild-type cells treated with SKF38393 alone $(\sim 1.2$-fold increase and $\sim 1$.3-fold increase, respectively; $p=0.97$ ) (Fig. $6 B$ ). In contrast, in mutant cells, higher levels of tau phosphorylation were detected when cells were preexposed to NMDA ( $\sim 2.6$-fold and $\sim 2.1$-fold, respectively; $p \leq$ 0.05 ) (Fig. $6 B$ ). These data suggest that mutant huntingtin induces enhanced Cdk5 activity that results in increased phosphorylation of tau, an effect that is exacerbated by activation of $D_{1} R$ alone or in combination with NMDAR.

Roscovitine ameliorates cell death evoked by SKF38393 and NMDA treatment in STHdh ${ }^{\text {Q111 }}$ cells

The previous data suggest that Cdk5 may act as a down-stream mediator of NMDA and SKF38393 neurotoxicity in striatal cells.
To test this hypothesis, we next evaluated the effect of roscovitine, a Cdk5 inhibitor, on NMDA and SKF38393-induced cell death. We found that roscovitine was able to significantly reverse the cell death induced by NMDA, SKF38393, or both in either wild-type and mutant huntingtin cells (Fig. 7). These findings demonstrate that a blockade of Cdk 5 by roscovitine correlates with a reduction of cell death induced by NMDAR and $D_{1} R$ activation in striatal cells and supports the involvement of aberrant Cdk5 activation in the increased vulnerability of mutant STHdh ${ }^{\text {Q111 }}$ striatal cells to NMDA and SKF38393 treatment.

\section{Cdk5 pathway is deregulated in $\mathrm{Hdh}^{\mathrm{Q} 111}$ knock-in mice and in HD human brain}

To determine the relevance of deregulation of Cdk5 pathway in an in vivo HD model, we next analyzed whether Cdk5 alteration was also detected in the striatum of mutant $H d h^{Q 111}$ mice. We first analyzed the levels of $\mathrm{Cdk} 5$ in striatal brain extracts obtained from mutant $H d h^{Q 111}$ mice and wild-type $H d h^{Q 7}$ littermate mice at 9 months of age. In agreement with our results on mutant striatal cells, immunoblot analysis revealed a significant increase in the ratio $\mathrm{p}-\mathrm{Tyr}^{15} \mathrm{Cdk} 5 / \mathrm{Cdk} 5$ in the striatum of mutant $H d h^{Q 111}$ mice compared with wildtype $H d h^{Q 7}$ mice ( $\sim 2$-fold; $p \leq 0.05$ ) (Fig. $8 A$ ). Moreover, decreased p35 expression $(\sim 2$-fold; $p \leq 0.01)$ and higher accumulation of 25 forms ( $\sim 2$-fold; $p \leq 0.01)$ were detected in 
A

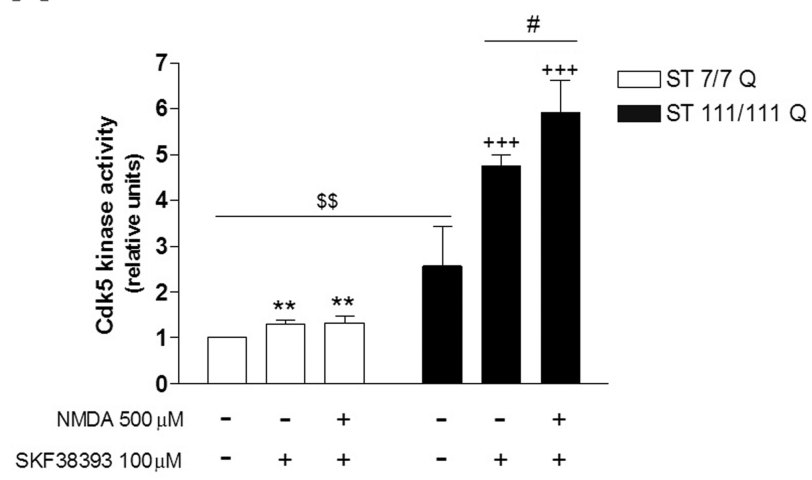

B
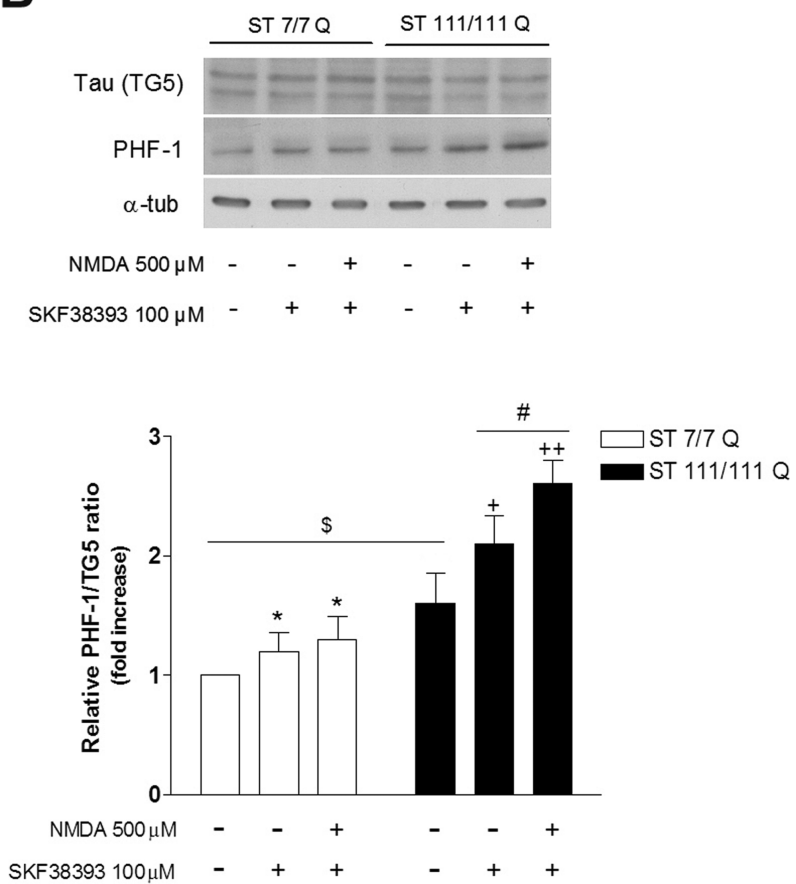

Figure 6. Mutant STHdh ${ }^{Q 111}$ striatal cells exhibit increased Cdk5 activity associated with higher tau phosphorylation. Wild-type (ST7/7Q) and mutant (ST111/111Q) striatal cells were treated with SKF38393 $(100 \mu \mathrm{m})$ or pretreated with NMDA $(500 \mu \mathrm{M})$ before SKF38393 exposure, and total cell extracts were obtained $30 \mathrm{~min}$ after treatment. $A$, In vitro kinase assay of immunoprecipitated $\mathrm{Cdk} 5$ from $500 \mu \mathrm{g}$ of whole-cell lysates was performed using $\mathrm{H} 1$ peptide as substrate. The histogram represents the $(\mathrm{d} k 5$ kinase activity in relative units corrected for the protein levels of C $\mathrm{dk} 5$ for each sample and refereed to control (vehicle-treated) wild-type cells. Values are given as mean $\pm S D$ of three independent experiments. ${ }^{* *} p<0.01$ treated versus vehicle-treated wild-type cells; ${ }^{+++} p<0.001$ treated versus vehicle-treated mutant cells; ${ }^{\$ \$} p<0.01$ vehicle-treated mutant cells versus vehicle-treated wild-type cells; ${ }^{\#} p<0.05$ NMDA plus SKF38393-treated mutant cells versus SKF38393-treated mutant cells as determined by one-way ANOVA followed by Bonferroni's multiple comparison test. $\boldsymbol{B}$, Representative Western blot showing total Tau (TG5) levels, phosphorylated Tau (PHF-1) levels, and $\alpha$-tubulin as a loading control from wild-type and mutant striatal cells. The histogram represents the relative PHF-1/TG5 ratio expressed as fold increase versus wild-type cells. Values are given as mean $\pm S D$ of three independent experiments. ${ }^{*} p<0.05$ treated versus vehicletreated wild-type cells; ${ }^{+} p<0.05,{ }^{++} p<0.01$ treated versus vehicle-treated mutant cells; ${ }_{p} p<0.05$ vehicle-treated mutant cells versus vehicle-treated wild-type cells; ${ }^{\#} p<0.05 \mathrm{NMDA}$ plus SKF38393-treated mutant cells versus SKF38393-treated mutant cells as determined by one-way ANOVA followed by Bonferroni's multiple comparison test.

mutant $H d h^{Q 111}$ striatal extracts compared with wild-type $H d h^{Q 7}$ striatal extracts (Fig. $8 A$ ). Finally, to determine whether increased Cdk5 phosphorylation and p 25 expression involved higher Cdk5 activity, we next examined the levels of
A
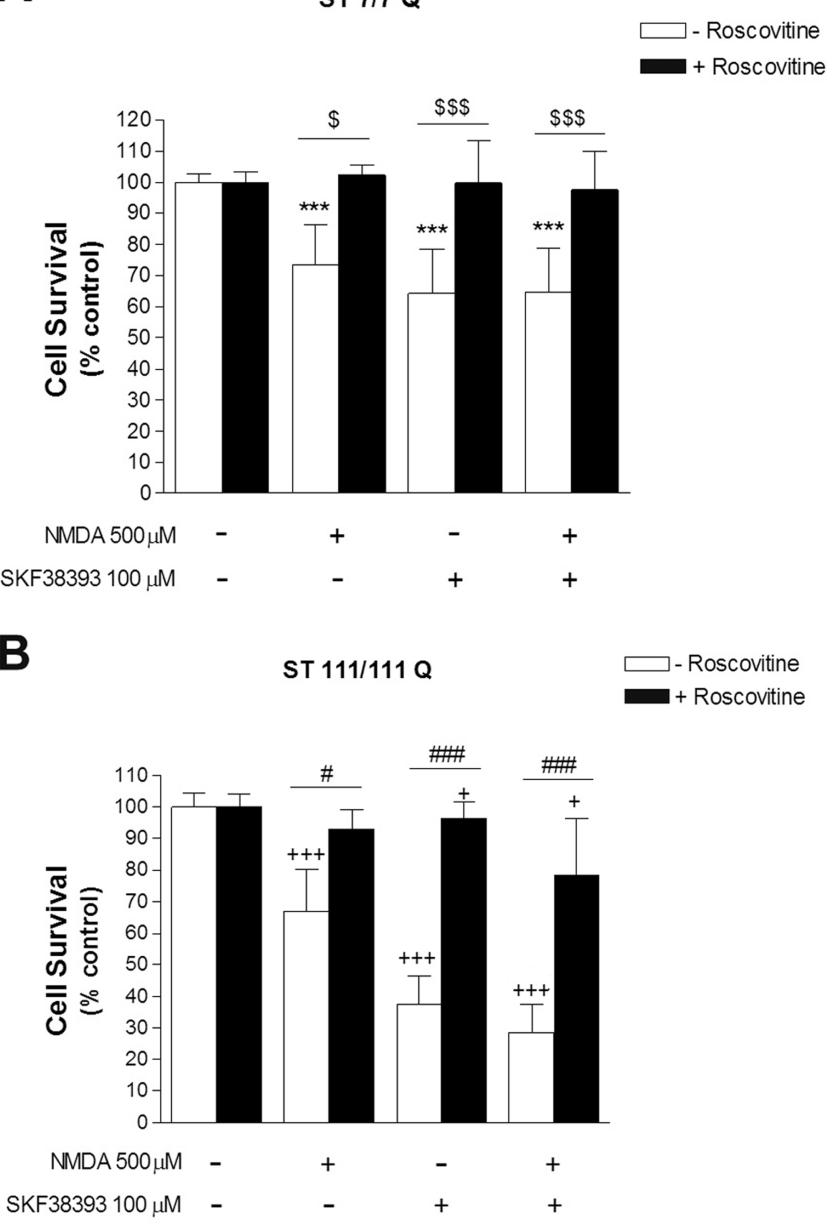

Figure 7. Inhibition of $\mathrm{Cdk} 5$ kinase activity by roscovitine ameliorates $S T H d \mathrm{dh}^{Q 111}$ cells from cell death induced by SKF38393 and NMDA treatment. $\boldsymbol{A}, \boldsymbol{B}$, Wild-type (ST7/7Q; $\boldsymbol{A}$ ) and mutant (ST111/111Q; $\boldsymbol{B}$ ) striatal cells pretreated $(1 \mathrm{~h})$ with the $\mathrm{Cdk}$ inhibitor roscovitine $(20 \mu \mathrm{M})$ were exposed to NMDA $(500 \mu \mathrm{M})$ or SKF38393 $(100 \mu \mathrm{m})$ alone, or preincubated with NMDA before SKF38393 exposure. Cell survival was evaluated $24 \mathrm{~h}$ later by scoring the percentage of Hoechststained nuclei. Forty fields were counted per condition per experiment, comprising at least $30-40$ cells. Results are expressed as percentage of control (vehicle-treated) cells, and data are the mean $\pm S D$ of three independent experiments performed in triplicate. ${ }^{* * *} p<0.001$ treated versus vehicle-treated wild-type cells; ${ }^{\$} p<0.05$, ${ }^{\$ \$ \$} p<0.001$ roscovitine-treated versus roscovitine-untreated wild-type cells; ${ }^{+} p<0.05,{ }^{+++} p<0.001$ treated versus vehicle-treated mutant cells; ${ }^{\#} p<0.05$, ${ }^{\# \# \#} p<0.001$ roscovitine-treated versus roscovitineuntreated mutant cells as determined by one-way ANOVA followed by Bonferroni's multiple comparison test.

tau phosphorylation. Western blot analysis revealed a significant increase of tau phosphorylation (PHF-1) in mutant $H d h^{\mathrm{Q} 111}$ striatal brain compared with wild-type $H d h^{\mathrm{Q7}}$ striatal brain ( $\sim 2$-fold; $p \leq 0.01$ ) (Fig. $8 B$ ). These results suggest that mutant huntingtin expression enhances Cdk5 activity in vivo by increasing Cdk5 phosphorylation and the conversion of p35 to p25, which results in aberrant phosphorylation of tau protein. Finally, we also investigated whether aberrant Cdk5 pathway was manifested in HD human brain. Western blot analysis confirmed a decrease of C $\mathrm{dk} 5$ in human striatal brain samples from HD patients compared with control brains (Fig. $8 C)$. Unfortunately, we failed to detect C $\mathrm{dk} 5$ phosphorylation (Tyr15) in human brain extracts probably because of the sensitivity of this phosphorylation site to postmortem intervals (range from 4 to $15 \mathrm{~h}$ for HD samples and from 4 to $23 \mathrm{~h}$ for control samples). Importantly, an increase of p25/p35 levels 
were also detected in HD human striatal brains compared with control striatal brains. Thus, HD striatal brains exhibited a significant decrease in p35 expression ( $\sim 3$-fold; $p \leq 0.05$ ) and increased p25 levels ( $\sim 4$-fold; $p \leq 0.001$ ) (Fig. $8 C$ ) compared with control striatal brains. These data support the view that aberrant Cdk5 pathway is also manifested in HD patients and suggest a role of p25/ Cdk5 in HD pathology.

\section{Discussion}

Degeneration of medium spiny neurons in the striatum is the main hallmark of HD neuropathology. However, the molecular mechanism by which mutant huntingtin toxicity causes such specific cell death remains unknown. Our present work demonstrates that fulllength mutant huntingtin enhances the sensitivity of striatal cells to dopamine leading to increased neuronal death. This effect on neurotoxicity is mediated by $D_{1}$ but not $D_{2}$ receptors as demonstrated by using specific dopaminereceptor agonists. Thus, the direct activation of $D_{1} R$ by SKF38393 revealed a higher dose-response reduction in cell survival in mutant STHdh ${ }^{\mathrm{Q} 11}$ than in wild-type STHdh ${ }^{\text {Q7 }}$ cells, an effect that was mostly reverted by the selective $D_{1}$ antagonist SCH23390. The lack of cell death in the presence of the $\mathrm{D}_{2}$ agonist quinpirole indicates that the neurotoxic effect of dopamine in knock-in mutant striatal cells is mainly associated with $\mathrm{D}_{1} \mathrm{R}$ activation. These results agree with previous reports indicating the role of $D_{1} R$ in striatal neuronal loss. It has been proposed that dopamine, by acting through activation of $\mathrm{D}_{1} \mathrm{R}$ and auto-oxidation, causes striatal neurotoxicity by inducing the neuronal expression and activity of inducible nitric oxide synthase (Wersinger et al., 2004). Moreover, dopamine through $D_{1} R$ potentiates glutamate-induced toxicity in cultured striatal cells from YAC128 HD mice (Tang et al., 2007). However, the involvement of $\mathrm{D}_{2} \mathrm{R}$ in $\mathrm{HD}$ pathology cannot be completely ruled out because dopamine via $\mathrm{D}_{2}$ receptors enhances mutant huntingtin aggregation and mitochondrial dysfunction in exon-1 HD mouse models (Charvin et al., 2005; Benchoua et al., 2008). Therefore, it is possible that at early disease stages that is in the absence of mutant huntingtin cleavage and aggregate formation, dopamine toxicity acts primarily via $D_{1} R$ whereas later in the disease progress altered $D_{1}$ and $D_{2}$ receptor signaling contribute to HD pathology.

It is well known that glutamate and dopamine receptors regulate striatal neuronal function by interacting and modulating each other. Specifically, an association between NMDAR and $D_{1} R$ has been reported, although the nature of this interaction remains unclear (Scott et al., 2002; Salter, 2003; Cepeda and Levine, 2006; Missale et al., 2006). Here, we have demonstrated that NMDA potentiates $\mathrm{D}_{1} \mathrm{R}$-induced cell death in mutant STH$\mathrm{dh}^{\mathrm{Q} 111}$ cells but not in wild-type STHdh ${ }^{\mathrm{Q} 7}$ cells. We have tested toxic NMDA concentrations, which induce similar cell death in wild-type and mutant cells and low NMDA concentrations,

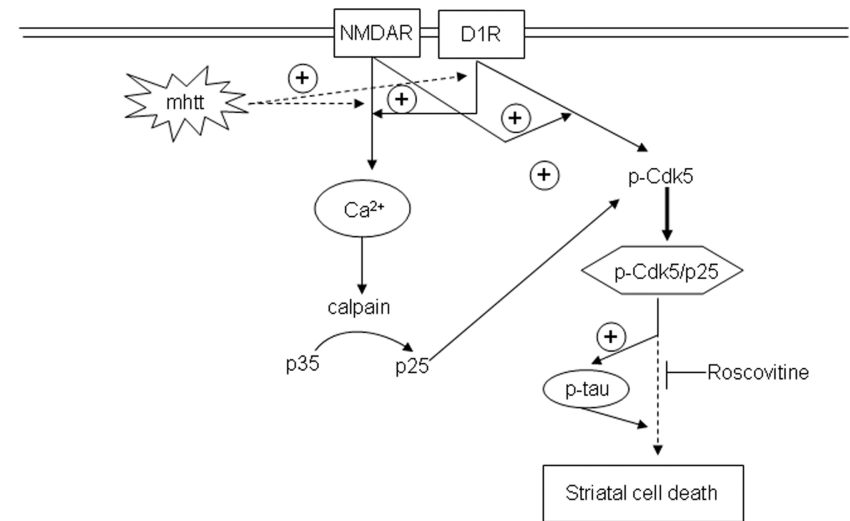

Figure 9. Increased sensitivity of mutant huntingtin striatal cells to glutamate and dopamine receptor activation involves enhanced C $d k 5$ activity. Hypothetical model to depict the link between neurotoxicity induced by dopamine and glutamate receptor activation and the C dk5 pathway in $H D$. Enhanced activation of NMDAR and $D_{1} R$ induced by mutant huntingtin leads to deregulation of calcium homeostasis (Cepeda et al., 2001; Seong et al., 2005; Starling et al., 2005; Tang et al., 2007). Increased intracellular calcium in turn leads to higher calpain activity that results in enhanced cleavage of p35 into p25 (Lee et al., 2000). In addition, as our data demonstrate, activation of NMDAR may potentiate $D_{1} R$-mediated phosphorylation of $C d k 5$ at $\mathrm{Tyr}^{15}$, which has been shown to regulate (dk5-induced neurotoxicity (Lin et al., 2007). The generation of $\mathrm{p}$-Cdk5/p25 complexes implies Cdk5 hyperactivation that is responsible for the phosphorylation of new substrates such as tau protein. Now, hyperphosphorylation of tau in concert with unknown yet down-stream p $25 / \mathrm{Cdk} 5$ effectors might contribute to striatal cell death and dysfunction and therefore to HD neuropathology. The model is supported by the capacity of roscovitine, a Cdk5 inhibitor, to prevent cellular death induced by NMDAR and $D_{1} R$ activation. 
which, per se, are not toxic (Xifró et al., 2008). Notably, either toxic or subtoxic NMDA concentrations enhanced the effect in cell death mediated by SKF38393 only in mutant STHdh ${ }^{\text {Q111 }}$ cells. These results agree with previous studies showing that glutamate and dopamine act synergistically to induce degeneration of striatal cells in YAC128 HD mouse models (Tang et al., 2007). Altogether, our data suggest that mutant huntingtin alters the dopaminergic and glutamatergic signaling not only by affecting NMDAR and $D_{1} R$ but also by altering the cross-talk between both pathways. Consequently, to gain a better understanding of how mutant huntingtin increases the vulnerability of striatal cells to neurotoxicity, we focused on defining the molecular mechanisms that underlie the toxic effect of NMDAR and $D_{1} R$ activation on striatal cell survival.

Recent studies have identified Cdk5 as mediator of dopaminergic neuronal loss in mouse models of Parkinson's disease because inhibition of $\mathrm{Cdk} 5$ reduces neurodegeneration and behavior disturbances in these mouse models (Smith et al., 2003, 2006; Przedborski, 2007). Moreover, it has been demonstrated that Cdk5 can regulate NMDAR signaling by direct phosphorylation of NR2A and NR2B subunits or indirectly via phosphorylation of postsynaptic density-95 (Morabito et al., 2004; Zhang et al., 2008). Therefore, it is reasonable to hypothesize a role for Cdk5 in the increased vulnerability of mutant huntingtin striatal cells to NMDAR and $D_{1} R$ activation.

We have examined two important features of Cdk5 activation related to its pro-apoptotic function: the levels of $\mathrm{Tyr}^{15}$ phosphorylation (Lin et al., 2007) and the accumulation of p25 as a result of calpain-mediated p35 cleavage (Kusakawa et al., 2000; Lee et al., 2000). Our results in knock-in striatal cells define a new role of mutant huntingtin as modulator of the Cdk5 pathway by (1) decreasing Cdk5 expression and increasing the levels of phosphorylated $\mathrm{Tyr}^{15}$-Cdk5 and (2) by increasing the conversion of p 35 into p25, which in turn results in enhanced Cdk5 activity. Moreover, we have demonstrated a polyQ-dependent reduction of Cdk5 expression together with an increase in $\mathrm{Tyr}^{15}$-Cdk5 phosphorylation in striatal cells. These data support the idea of a direct role of mutant huntingtin in Cdk5 changes rather than a secondary consequence of mutant huntingtin toxicity. Consistent with the results obtained in the knock-in striatal cell line, we also found deregulation of Cdk5 in $H d h^{Q 111}$ knock-in mice and HD human brain. Our studies demonstrate an increased of $\mathrm{p}-\mathrm{Tyr}^{15}$-Cdk5/ Cdk5 ratio and a significant accumulation of p25 together with reduced p35 expression in the striatum of $\mathrm{Hdh}^{\mathrm{Q} 111} \mathrm{mu}$ tant mice and HD human brain. In agreement with these results, Anne et al. (2007) have reported reduced levels of Cdk5 and p35 in HD human brain, although no data on p25 accumulation was reported. These data are relevant because it has been demonstrated a protective role of p35/Cdk5 complexes in HD. Phosphorylation of mutant huntingtin by p35/Cdk5 complexes reduces huntingtin cleavage by caspases resulting in attenuated aggregate formation and toxicity (Luo et al., 2005). Moreover, phosphorylation of wild-type huntingtin by Cdk5 protects striatal cells against DNA damage (Anne et al., 2007). Both reports speculate that loss of p35/Cdk5 function may have detrimental consequences for HD pathology. Therefore, our novel results demonstrating an accumulation of p25 in HD mouse brain and striatal cell models and in HD human brain might be relevant to explain the apparent dual role of $\mathrm{Cdk} 5$ in HD pathology. Indeed, it is well established the role of p25 as a cell death inductor (Cruz and Tsai, 2004; Dhariwala and Rajadhyaksha, 2008). Thus, neurotoxicity induced by $\beta$-amyloid, ischemia, or MPTP causes aberrant Cdk5 activity through the generation and accumulation of p25 (Cruz and Tsai, 2004; Dhariwala and Rajadhyaksha, 2008). Furthermore, this truncated p 25 form relocalizes Cdk5 activity with the consequent alteration of Cdk5 substrate specificity (Patrick et al., 1999; Ko et al., 2001; Bian et al., 2002). Actually, elevated Cdk5 activity accumulation of p25 and hyperphosphorylated tau have been described in brain of AD patients (Cruz and Tsai, 2004; Dhariwala and Rajadhyaksha, 2008). Notably, our studies have identified tau as a downstream target of aberrant Cdk5 activity in HD mouse and striatal cell models. The specific role of tau in HD pathology remains to be elucidated. However, given evidence of impaired axonal trafficking in HD (Truant et al., 2006), it seems reasonable to speculate that altered tau may be involved in the vesicular trafficking deficiencies associated to HD pathology.

Collectively, our results clearly demonstrate that mutant huntingtin deregulates Cdk5 pathway. However, one important question is to determine whether aberrant Cdk5 activity plays a role in the increased sensitivity of mutant huntingtin cells to NMDAR and $D_{1} R$ activation. Indeed, our data indicate that deregulated Cdk5 pathway might be instrumental in the HD neurodegenerative process by increasing the vulnerability of striatal cells to dopamine and glutamate inputs. This conclusion is supported by the following observations: first, SKF38393 induced higher Cdk5 phosphorylation and activity in mutant cells than in wild-type cells. Second, exposure of mutant cells to NMDA before SKF38393 induced higher levels of Cdk5 phosphorylation and activity than in wild-type cells or mutant cells treated with SKF38393 alone. Third, compared with wild-type cells, increased levels of phosphorylated tau were detected in mutant striatal cells treated with SKF38393 alone or pre-exposed to NMDA. Therefore, these data demonstrate that mutant huntingtin increases the sensitivity of striatal cells to dopamine and glutamate inputs by altering a common NMDAR and $\mathrm{D}_{1} \mathrm{R}$ downstream pathway such is Cdk5. Supporting this conclusion are the findings that the inhibition of Cdk5 activity by roscovitine mainly prevented striatal cell death induced by NMDA, SKF38393, or both. However, because neuronal loss induced by NMDA and SKF38393 cotreatment was not fully prevented by roscovitine in mutant cells, we can speculate that additional mechanism independent of Cdk5 might be involved in the toxicity associated to NMDAR and $\mathrm{D}_{1} \mathrm{R}$ activation.

Based on these findings, an attractive model of striatal cell death is one in which aberrant Cdk5 activity (Fig. 6) as a result of enhanced Cdk5 phosphorylation at $\mathrm{Tyr}^{15}$ (Fig. 4) and $\mathrm{p} 25$ accumulation (Fig. 5) might sensitize mutant huntingtin striatal cells to NMDAR and $\mathrm{D}_{1} \mathrm{R}$ activation. Therefore, once NMDAR and $D_{1} R$ were activated, both receptors might act coordinately to promote calcium homeostasis deregulation (Cepeda et al., 2001; Starling et al., 2005; Tang et al., 2007) with the consequent mitochondrial depolarization and caspase activation (Zeron et al., 2002, 2004). In addition, as our data demonstrate, the activation of NMDAR may further potentiate $\mathrm{D}_{1} \mathrm{R}$-mediated phosphorylation of Cdk5, leading to the generation of $\mathrm{p}-\mathrm{Cdk} 5 / \mathrm{p} 25$ complexes and enhanced Cdk5 activity. Sustained Cdk5 activity may now target for phosphorylation different substrates such as tau or additional recognized Cdk5 effectors (Gong et al., 2003; Lee et al., 2007) and contribute to striatal cell death in HD.

In conclusion, our results provide evidence that aberrant Cdk5 activity is involved in the increased sensitivity of mutant 
huntingtin striatal cells to dopamine and glutamate inputs and reveal p25/Cdk5 complexes as potential candidates for future pharmacological intervention in HD (Fig. 9).

\section{References}

Akashiba H, Ikegaya Y, Nishiyama N, Matsuki N (2008) Differential involvement of cell cycle reactivation between striatal and cortical neurons in cell death induced by 3-nitropropionic acid. J Biol Chem 283:6594-6606.

Anne SL, Saudou F, Humbert S (2007) Phosphorylation of huntingtin by cyclin-dependent kinase 5 is induced by DNA damage and regulates wildtype and mutant huntingtin toxicity in neurons. J Neurosci 27:7318-7328.

Beal MF, Brouillet E, Jenkins BG, Ferrante RJ, Kowall NW, Miller JM, Storey E, Srivastava R, Rosen BR, Hyman BT (1993) Neurochemical and histologic characterization of striatal excitotoxic lesions produced by the mitochondrial toxin 3-nitropropionic acid. J Neurosci 13:4181-4192.

Benchoua A, Trioulier Y, Diguet E, Malgorn C, Gaillard MC, Dufour N, Elalouf JM, Krajewski S, Hantraye P, Déglon N, Brouillet E (2008) Dopamine determines the vulnerability of striatal neurons to the $\mathrm{N}$-terminal fragment of mutant huntingtin through the regulation of mitochondrial complex II. Hum Mol Genet 17:1446-1456.

Bian F, Nath R, Sobocinski G, Booher RN, Lipinski WJ, Callahan MJ, Pack A, Wang KK, Walker LC (2002) Axonopathy, tau abnormalities and dyskinesia, but no neurofibrillary tangles in p25-transgenic mice. J Comp Neurol 446:257-266.

Brecht S, Kirchhof R, Chromik A, Willesen M, Nicolaus T, Raivich G, Wessig J, Waetzig V, Goetz M, Claussen M, Pearse D, Kuan CY, Vaudano E, Behrens A, Wagner E, Flavell RA, Davis RJ, Herdegen T (2005) Specific pathophysiological functions of JNK isoforms in the brain. Eur J Neurosci 21:363-377.

Centeno C, Repici M, Chatton JY, Riederer BM, Bonny C, Nicod P, Price M, Clarke PG, Papa S, Franzoso G, Borsello T (2007) Role of the JNK pathway in NMDA-mediated excitotoxicity of cortical neurons. Cell Death Differ 14:240-253.

Cepeda C, Levine MS (2006) Where do you think you are going? The NMDA-D ${ }_{1}$ receptor trap. Sci STKE: 333:pe20.

Cepeda C, Ariano MA, Calvert CR, Flores-Hernández J, Chandler SH, Leavitt BR, Hayden MR, Levine MS (2001) NMDA receptor function in mouse models of Huntington disease. J Neurosci Res 66:525-539.

Charvin D, Vanhoutte P, Pagès C, Borrelli E, Borelli E, Caboche J (2005) Unraveling a role for dopamine in Huntington's disease: the dual role of reactive oxygen species and $\mathrm{D}_{2}$ receptor stimulation. Proc Natl Acad Sci U S A 102:12218-12223.

Crespo-Biel N, Camins A, Pelegrí C, Vilaplana J, Pallàs M, Canudas AM (2007) 3-Nitropropionic acid activates calpain/cdk5 pathway in rat striatum. Neurosci Lett 421:77-81.

Cruz JC, Tsai LH (2004) A Jekyll and Hyde kinase: roles for Cdk5 in brain development and disease. Curr Opin Neurobiol 14:390-394.

Cyr M, Sotnikova TD, Gainetdinov RR, Caron MG (2006) Dopamine enhances motor and neuropathological consequences of polyglutamine expanded huntingtin. FASEB J 20:2541-2543.

de la Monte SM, Vonsattel JP, Richardson EP Jr (1988) Morphometric demonstration of atrophic changes in the cerebral cortex, white matter, and neostriatum in Huntington's disease. J Neuropathol Exp Neurol 47:516-525.

Dhariwala FA, Rajadhyaksha MS (2008) An unusual member of the cdk family: cdk5. Cell Mol Neurobiol 28:351-369.

Fan MM, Raymond LA (2007) N-methyl-D-aspartate (NMDA) receptor function and excitotoxicity in Huntington's disease. Prog Neurobiol 81:272-293.

Gines S, Ivanova E, Seong IS, Saura CA, MacDonald ME (2003) Enhanced Akt signaling is an early pro-survival response that reflects N-methyl-Daspartate receptor activation in Huntington's disease knock-in striatal cells. J Biol Chem 278:50514-50522.

Gong X, Tang X, Wiedmann M, Wang X, Peng J, Zheng D, Blair LA, Marshall J, Mao Z (2003) Cdk5-mediated inhibition of the protective effects of transcription factor MEF2 in neurotoxicity-induced apoptosis. Neuron 38:33-46.

Jakel RJ, Maragos WF (2000) Neuronal cell death in Huntington's disease: a potential role for dopamine. Trends Neurosci 23:239-245.
Kazantsev A, Preisinger E, Dranovsky A, Goldgaber D, Housman D (1999) Insoluble detergent-resistant aggregates form between pathological and nonpathological lengths of polyglutamine in mammalian cells. Proc Natl Acad Sci U S A 96:11404-11409.

Ko J, Humbert S, Bronson RT, Takahashi S, Kulkarni AB, Li E, Tsai LH (2001) p35 and p39 are essential for cyclin-dependent kinase 5 function during neurodevelopment. J Neurosci 21:6758-6771.

Kusakawa G, Saito T, Onuki R, Ishiguro K, Kishimoto T, Hisanaga S (2000) Calpain-dependent proteolitic cleavage of the p35 cyclin-dependent kinase 5 activator to p25. J Biol Chem 275:17166-17172.

Lee JH, Kim HS, Lee SJ, Kim KT (2007) Stabilization and activation of p53 induced by Cdk5 contributes to neuronal cell death. J Cell Sci 120:2259-2271.

Lee MS, Kwon YT, Li M, Peng J, Friedlander RM, Tsai LH (2000) Neurotoxicity induces cleavage of p35 to p25 by calpain. Nature 405:360-364.

Lin H, Lin TY, Juang JL (2007) Abl deregulates Cdk5 kinase activity and subcellular localization in Drosophila neurodegeneration. Cell Death Differ 14:607-615.

Luo S, Vacher C, Davies JE, Rubinsztein DC (2005) Cdk5 phosphorylation of huntingtin reduces its cleavage by caspases: implications for mutant huntingtin toxicity. J Cell Biol 169:647-656.

MacDonald ME, Gines S, Gusella JF, Wheeler VC (2003) Huntington's disease. Neuromolecular Med 4:7-20.

Martin JB, Gusella JF (1986) Huntington's disease. Pathogenesis and management. N Engl J Med 315:1267-1276.

Missale C, Fiorentini C, Busi C, Collo G, Spano PF (2006) The NMDA/D receptor complex as a new target in drug development. Curr Top Med Chem 6:801-808.

Morabito MA, Sheng M, Tsai LH (2004) Cyclin-dependent kinase 5 phosphorylates the N-terminal domain of the postsynaptic density protein PSD-95 in neurons. J Neurosci 24:865-876.

Patrick GN, Zukerberg L, Nikolic M, de la Monte S, Dikkes P, Tsai LH (1999) Conversion of p35 to p25 deregulates Cdk5 activity and promotes neurodegeneration. Nature 402:615-622.

Pérez-Navarro E, Canals JM, Ginés S, Alberch J (2006) Cellular and molecular mechanisms involved in the selective vulnerability of striatal projection neurons in Huntington's disease. Histol Histopathol 21:1217-1232.

Przedborski S (2007) Peroxiredoxin-2 links Cdk5 to neurodegeneration. Nat Med 13:907-909.

Salter MW (2003) $D_{1}$ and NMDA receptor hook up: expanding on an emerging theme. Trends Neurosci 26:235-237.

Scott L, Kruse MS, Forssberg H, Brismar H, Greengard P, Aperia A (2002) Selective up-regulation of dopamine $\mathrm{D}_{1}$ receptors in dendritic spines by NMDA receptor activation. Proc Natl Acad Sci USA 99:1661-1664.

Seong IS, Ivanova E, Lee JM, Choo YS, Fossale E, Anderson M, Gusella JF, Laramie JM, Myers RH, Lesort M, MacDonald ME (2005) HD CAG repeat implicates a dominant property of huntingtin in mitochondrial energy metabolism. Hum Mol Genet 14:2871-2880.

Smith PD, Crocker SJ, Jackson-Lewis V, Jordan-Sciutto KL, Hayley S, Mount MP, O'Hare MJ, Callaghan S, Slack RS, Przedborski S, Anisman H, Park DS (2003) Cyclin-dependent kinase 5 is a mediator of dopaminergic neuron loss in a mouse model of Parkinson's disease. Proc Natl Acad Sci U S A 100:13650-13655.

Smith PD, Mount MP, Shree R, Callaghan S, Slack RS, Anisman H, Vincent I, Wang X, Mao Z, Park DS (2006) Calpain-regulated p35/cdk5 plays a central role in dopaminergic neuron death through modulation of the transcription factor myocyte enhancer factor 2. J Neurosci 26:440-447.

Starling AJ, André VM, Cepeda C, de Lima M, Chandler SH, Levine MS (2005) Alterations in N-methyl-D-aspartate receptor sensitivity and magnesium blockade occur early in development in the R6/2 mouse model of Huntington's disease. J Neurosci Res 82:377-386.

Tang TS, Chen X, Liu J, Bezprozvanny I (2007) Dopaminergic signaling and striatal neurodegeneration in Huntington's disease. J Neurosci 27:7899-7910.

Trettel F, Rigamonti D, Hilditch-Maguire P, Wheeler VC, Sharp AH, Persichetti F, Cattaneo E, MacDonald ME (2000) Dominant phenotypes produced by the HD mutation in STHdh(Q111) striatal cells. Hum Mol Genet 9:2799-2809. 
Truant R, Atwal R, Burtnik A (2006) Hypothesis: Huntingtin may function in membrane association and vesicular trafficking. Biochem Cell Biol 84:912-917.

Wersinger C, Chen J, Sidhu A (2004) Bimodal induction of dopaminemediated striatal neurotoxicity is mediated through both activation of $\mathrm{D}_{1}$ dopamine receptors and autoxidation. Mol Cell Neurosci 25:124-137.

Wheeler VC, Auerbach W, White JK, Srinidhi J, Auerbach A, Ryan A, Duyao MP, Vrbanac V, Weaver M, Gusella JF, Joyner AL, MacDonald ME (1999) Length-dependent gametic CAG repeat instability in the Huntington's disease knock-in mouse. Hum Mol Genet 8:115-122.

Xifró X, García-Martínez JM, Del Toro D, Alberch J, Pérez-Navarro E (2008) Calcineurin is involved in the early activation of NMDA-mediated cell death in mutant huntingtin knock-in striatal cells. J Neurochem 105:1596-1612.
Zeron MM, Hansson O, Chen N, Wellington CL, Leavitt BR, Brundin P, Hayden MR, Raymond LA (2002) Increased sensitivity to N-methyl-Daspartate receptor-mediated excitotoxicity in a mouse model of Huntington's disease. Neuron 33:849-860.

Zeron MM, Fernandes HB, Krebs C, Shehadeh J, Wellington CL, Leavitt BR, Baimbridge KG, Hayden MR, Raymond LA (2004) Potentiation of NMDA receptor-mediated excitotoxicity linked with intrinsic apoptotic pathway in YAC transgenic mouse model of Huntington's disease. Mol Cell Neurosci 25:469-479.

Zhang S, Edelmann L, Liu J, Crandall JE, Morabito MA (2008) Cdk5 regulates the phosphorylation of tyrosine 1472 NR2B and the surface expression of NMDA receptors. J Neurosci 28:415-424. 